\title{
Capacity of discontinuous egg development and its importance for the geographic distribution of the warm water stenotherm, Dinocras cephalotes (Insecta: Plecoptera: Perlidae)
}

\section{P. Zwick1}

Keywords : Plecoptera, Perlidae, discontinuous egg development, parapause, geographic distribution.

Aspects of the egg biology of the perlid stonefly, Dinocras cephalotes (Curtis), were studied experimentally. Development under constant laboratory conditions did not differ from development under variable field conditions. Exposure to $4^{\circ} \mathrm{C}$, the lower threshold temperature for egg development, caused abrupt interruptions of embryonic development. Development was resumed after return to favourable temperatures, with an approximate two-week-delay. Up to six interruptions of egg development did not negatively affect hatching success, regardless of developmental stage at which disturbances occurred. However, the older embryos grew, the more rapidly development was resumed after a cold disturbance; embryos from fully developed eggs hatched even at $4^{\circ} \mathrm{C}$, although this is too cold to support larval growth. While eggs at $4^{\circ} \mathrm{C}$ remain dormant and vital for long periods of time, eggs exposed to suboptimal temperatures $\left(10^{\circ} \mathrm{C}\right)$ remain only temporarily dormant and eventually develop and hatch.

D. cephalotes is assumed to satisfy its high thermal demand for egg development under harsh conditions, for example in arctic Scandinavia, by opportunistically using summer warmth and spreading embryogenesis over more than one year. I suggest that high cue temperatures required to initiate egg development in Scandinavian populations are adaptive and ensure that larvae in the Arctic hatch under favourable seasonal conditions.

Capacité de développement discontinu de l'œuf et son importance dans la distribution géographique du Plécoptère sténotherme d'eau chaude Dinocras cephalotes (Insecta : Plecoptera : Perlidae)

Mots clés : Plecoptera, Perlidae, développement discontinu de l'œuf, parapausé, distribution géographique.

Certains aspects de la biologie de l'œuf du Plécoptère Perlidae, Dinocras cephalotes (Curtis) ont été étudiés expérimentalement. Le développement dans des conditions constantes de laboratoire ne differe pas de celui sous des conditions variables en milieu naturel. Une exposition à $4^{\circ} \mathrm{C}$, température minimale requise pour le développement de l'œuf, entraîne de brusques interruptions du développement embryonnaire. Le retour à une température favorable entraîne une reprise du développement dans un délai d'environ 2 semaines. Jusqu'à 6 interruptions du développement de l'œuf n'empêchent pas le succès de l'éclosion, indépendamment de l'état de développement auquel se produisent les perturbations. Cependant, plus les embryons sont âgés, plus le développement reprend rapidemènt après une baisse de température ; des embryons issus d'œufs entièrement développés éclosent même à $4^{\circ} \mathrm{C}$ bien que cette température soit trop basse pour permettre la croissance larvaire. Alors que des cufs à $4^{\circ} \mathrm{C}$ peuvent rester en dormance pendant de longues périodes, des œufs exposés à des températures suboptimales $\left(10^{\circ} \mathrm{C}\right)$ ne restent que temporairement en dormance pour se développer et éclore finalement.

Sous des conditions climatiques sévères, par exemple en Scandinavie, $D$. cephalotes est supposé satisfaire ses forts besoins - thërmiques nécessaires au développement des œufs par l'utilisation opportuniste de la chaleur estivale et par l'étalement de l'embryogénèse sur plus d'un an. Je suggère que les hautes températures requises comme signal pour déclencher le développement des oufs dans les populations scandinaves constituent une adaptation qui permet aux larves de l'arctique d'éclore lorsque les conditions saisonnières sont favorables. 


\section{Introduction}

The large carnivorous stoneflies of the family Perlidae attain their greatest taxonomic diversity in warm temperate or even tropical areas but are also present in temperate climates. The European perlid fauna is relatively poor, diversity is greatest in areas not affected by Pleistocene glaciations and declines towards northern latitudes (Fig. 1). Continental north-east Europe is void of Perlidae, and the single perlid species in Scandinavia is Dinocras cephalotes (Curtis).

The genus Dinocras is endemic in Europe, its three species are very similar, and speciation may have occurred during Pleistocene separations. While two $D i$ nocras species have restricted central and south European distributions, D. cephalotes has the widest range among all European Perlidae, from the extreme south $\left(37^{\circ} \mathrm{N}\right.$; Sanchez-Ortega \& Alba-Tercedor 1991) to the extreme north $\left(70^{\circ} \mathrm{N}\right.$; Huru 1987 , Lillehammer 1988$)$ of Europe (Fig. 2).

D. cephalotes is of Mediterranean origin and was rightly called a warm water stenotherm (Elliott 1989, 1995). The influence of incubation temperature $\left[{ }^{\circ} \mathrm{C}\right]$ on mean egg incubation period [number of days until mean hatch, i.e., $50 \%$ of all larvae that eventually hatch have actually hatched; Brittain 1977] of Dinocras spp. is unusually strong, among stoneflies, and total thermal demand for egg development ( $c a 600$ degreedays above $4^{\circ}$ : Zwick 1996) is not fulfilled in a single year in all of the range.

Eggs of $D$. cephalotes do not develop at all temperatures above freezing point. The lower threshold temperature where embryogenesis stops and eggs enter parapause (in the sense of Müller 1992) is just above $4^{\circ} \mathrm{C}$. In the dormant state eggs remain vital for a long time and may form a seed bank (Zwick 1996) from which larvae hatch under more favourable climatic conditions. To end the parapause and initiate (or resume) embryogenesis, water must reach a cue temperature which is distinctly above the actual lower threshold temperature for development. The cue temperature triggering development is not the same throughout the range of the species, although the lower threshold temperature proper was always near $4^{\circ}$, also in a Slovenian population of the closely related $D$. megacephala (Klapálek).

For the Dinocras spp. so far studied (Elliott 1989, Lillehammer 1986, Zwick 1996), there is a distinct geographical cline of the cue temperature (Fig. 2) which appears paradoxical: at high latitudes, where least thermal energy is annually available, the highest cue temperatures initiating development are required; this further reduces time available for development in a given year.
Matters are complicated by the fact that in a given population and even among siblings in a single egg mass the cue temperature is not uniform; there is evidence that variability of this trait is genetically determined (Zwick 1996). The cue temperature ranges from $8-14^{\circ}$ in German material (from $48-51^{\circ} \mathrm{N}$ ) but only from $12-14^{\circ}$ in Norwegian eggs (from $61^{\circ} \mathrm{N}$ ); development does not start in colder water (Zwick 1996).

The problem how $D$. cephalotes eggs can satisfy their high thermal demand under harsh climatic conditions, for example in North Europe, was not answered by previous studies. Egg development is here suggested to last longer than one year, permitting opportunistic use of warmth during more than one summer, until total thermal demand is fulfilled. However, this is only possible if development can be interrupted and resumed, according to temperature, without major damage to the embryos.

The present paper describes experiments addressing the following questions:

1. Are D. cephalotes eggs able to interrupt and resume development repeatedly according to environmental temperature, without greatly reduced hatching success?

2. Does stage of egg development have an influence on the outcome?

3. Does development under seasonal temperature and light regimes differ from development under constant laboratory conditions?

4. Do eggs not developing spontaneously at, e.g., $10^{\circ}$, remain in parapause for long, or do they eventually develop under the same suboptimal conditions?

5. What happens to fully developed eggs if temperature falls distinctly after larvae began hatching ?

\section{Material and methods}

Egg masses were collected in June, between 1991 and 1995, in Germany; most came from Hesse, Rhön Mts., Birxbach at Seiferts [50 $31^{\prime} \mathrm{N}, 10^{\circ} 01^{\prime} \mathrm{E}$ ] (Code $\mathrm{H}^{*}$ ), others from Thuringia, Thuringian Forest, Zahme Gera at Geraberg [50 $\left.53^{\prime} \mathrm{N}, 10^{\circ} 50^{\prime} \mathrm{E}\right]$ (Code T*), and from Bavaria, Iller River at Kempten [47 $43^{\prime} \mathrm{N}$, $10^{\circ} 19^{\prime} \mathrm{E}$ ] (Code $\mathrm{B}^{*}$ ), respectively.

A detailed description of methods was recently published (Zwick 1996). Briefly, egg masses were flushed off female abdomens into wide $15 \mathrm{ml}$ glass vials containing only ca $3 \mathrm{ml}$ stream water. Large batches were sometimes split into subsamples, each of over 100 eggs, which permitted tests of siblings from one egg mass under different conditions. Vials with eggs were placed in incubators providing various constant 
temperatures (Marten 1990a), under a constant 14/10 hr light/dark regime. Eggs were usually inspected daily, and hatchlings counted and removed.

To answer Question 1, eggs in the laboratory were alternately exposed to temperatures where all $D$. cephalotes populations so far examined develop reliably (14 $4^{\circ}$ during experiments in 1991 and $16^{\circ}$ during experiments in 1992), and to $4^{\circ}$ which is below the threshold temperature and prevents development (Zwick 1996). Transfer of vials between the different temperature chambers was abrupt.

A possible influence of developmental stage was tested by changing temperature at 2, 3, 4, and 5 week intervals so that different stages of development were affected. In each case, eggs remained at the cold or warm temperature, respectively, for the same length of time. The 2- and 4-week experiments in 1991 started at $14^{\circ}$. In 1992, material was more abundant and parallel 3and 5-week experiments at different phase, one starting at high, the other at low temperature were possible; however, material was insufficient for additional 2- and 4-week experiments starting at $4^{\circ}$.

Question 3 was addressed by incubating 6 small egg masses of $D$. cephalotes in the Breitenbach, a summercool stream at Schlitz (Germany, Hesse, $50^{\circ} 40^{\prime} \mathrm{N}$, $9^{\circ} 33^{\prime} \mathrm{E}, 220 \mathrm{~m}$ a.s.1.). This experiment repeated and expanded an earlier test for modifying effects of natural daylength and fluctuating temperatures (Zwick 1996).

In 1995/96, Question 4 was examined by incubating $11 \mathrm{egg}$ masses at a mean of $10^{\circ} \mathrm{C}( \pm 1.46$ s.d.). At this temperature, only part of the eggs develop spontaneously while others remain in parapause. Unlike in previous experiments (Zwick 1996) eggs remaining undeveloped at $10^{\circ}$ were continuously kept at that same temperature, for up to 420 days.

Question 5 was investigated by examining the effect of abrupt drastic cooling of fully developed eggs from which larvae had started hatching. 15 developed egg masses from which massive hatching had begun at $19^{\circ}$ were moved to $4^{\circ}$; after 75 days at $4^{\circ}$, temperature was raised to $20^{\circ}$, later to $30^{\circ}$.

All temperatures are in ${ }^{\circ} \mathrm{C}$. Data that are means are followed by indications of the range, in parentheses.

\section{Results}

\subsection{Interruptions and resumptions of egg develop- ment}

Eggs survived repeated cooling and interruptions of development, and hatching success was generally good (Table 1).
With a single exception (Batch HG in Fig. 7), eggs spent more days in 14 or $16^{\circ}$ warm water, respectively, until mean hatch than would be expected for mean incubation periods during continuous incubation at the same respective temperatures (Zwick 1996). The delay was related to the number of cooling events eggs had experienced; it was roughly two weeks for each interruption of development during cold exposure (Table 2).

Cumulative hatching curves differed between and within treatments, undisturbed unimodal hatching patterns (Figs. 3,6) were exceptional. Many curves included striking plateaus indicating halts of hatching for some time (e.g., Figs. 4, 5, 7); usually, plateaus separated distinct hatching pulses. Stops and resumptions of hatching were unrelated to momentary temperature regime but were apparently «echoes» of previous cold exposure.

Most interruptions of hatching lasted longer than the preceding cold spells. If several halts occurred during an experiment, halts grew successively shorter (Figs. $4,7)$.

In the two-week-interval treatment (Fig. 3) eggs were exposed to four 15-day-periods at $4^{\circ}$. When eggs were 121 days old there was still no visible development. From thereon, eggs were continuously kept at $14^{\circ}$; subsequent hatching was synchronous and mean hatch was attained when egg masses were 188 to 193.5 days old.

The two parallel runs of the three-week-interval treatments differed. Hatching success from eggs exposed to $4^{\circ}$ at the start of the experiment was insignificant ( 3 batches) or low (1 batch, ca 30\%) by Day 251 when the samples were accidentally destroyed. In the parallel experiment, eggs first exposed to $16^{\circ}$ for 21 days yielded many larvae after Day 200, during their fifth cold exposure (Fig. 4).

The response of eggs to the four-week-interval treatment (Fig. 5) was uniform; start, interruption and resumption of hatching occurred simultaneously. Hatching was interrupted for 44 (40-47) days while the cool period at $4^{\circ}$ had lasted only 30 days.

Eggs exposed to temperature changes at five-weekintervals starting in warm water hatched synchronously; cumulative curves were simple; Fig. 6 shows the fastest and the slowest of the 4 samples.

Cumulative hatching curves for eggs initially exposed to $4^{\circ}$ in the parallel experiment (Fig. 7) started synchronous hatching around Day 120; one egg mass attained mean hatch before the first halt of hatching. Hatching was repeatedly interrupted, cumulative hat- 
Table 1. Dinocras cephalotes, Bavarian (B), Hessian $(\mathrm{H})$ and Thuringian $(\mathrm{T})$ batches: number of larvae hatched during various treatments (temperature changes at two- to five-week intervals beginning in the cold at $4^{\circ} \mathrm{C}(/ \mathrm{c})$ and in the warm at 14 or $16^{\circ} \mathrm{C}(/ \mathrm{w})$, respectively) and overall hatching success [\% of all eggs in batch].

Tableau 1. Dinocras cephalotes, lots de Bavière (B), Hesse (H) et Thuringe (T) : nombres de larves écloses selon différents traitements (changements de température à intervalles de 2 à 5 semaines, débutant respectivement dans le froid à $4^{\circ} \mathrm{C}(/ \mathrm{c})$ et dans le chaud à $14^{\circ}$ ou $16^{\circ} \mathrm{C}(/ \mathrm{w})$ et succès total des éclosions (\% de tous les œufs du lot).

\begin{tabular}{|c|c|c|c|}
\hline Batch & Treatment & No. of Larvae & Hatching Success [\%] \\
\hline B5 & 2-week/w & 73 & 67 \\
\hline $\mathrm{H} 8$ & 2-week/w & 101 & 91 \\
\hline $\mathrm{H9}$ & 2-week/w & 93 & 92 \\
\hline $\mathrm{H} 14$ & 2-week/w & 244 & 91 \\
\hline $\mathrm{TB}$ & 2-week/w & 121 & 88 \\
\hline $\mathrm{HA}$ & 3-week/w & 223 & 84 \\
\hline $\mathrm{HC}$ & 3-week/w & 340 & 73 \\
\hline HD & 3-week/w & 195 & 57 \\
\hline $\mathrm{HI}$ & 3-week/w & 86 & 81 \\
\hline B5 & 4 -week/w & 118 & 64 \\
\hline B6 & 4-week/w & 58 & 59 \\
\hline $\mathrm{H} 8$ & 4-week/w & 107 & 92 \\
\hline $\mathrm{H9}$ & 4-week/w & 94 & 90 \\
\hline $\mathrm{HI} 4$ & 4-week/w & 223 & 54 \\
\hline $\mathrm{TB}$ & 4-week/w & 36 & (mildewed) 29 \\
\hline $\mathrm{HB}$ & 5 -week/w & 81 & 92 \\
\hline $\mathrm{HE}$ & 5 -week/w & 270 & 90 \\
\hline HK & 5-week/w & 322 & 87 \\
\hline $\mathrm{HF}$ & 5 -week/w & 36 & 92 \\
\hline $\mathrm{HA}$ & 5-week/c & 433 & 93 \\
\hline $\mathrm{HC}$ & 5-week/c & 854 & 92 \\
\hline $\mathrm{HD}$ & 5-week/c & 600 & 91 \\
\hline HG & 5-week/c & 47 & 96 \\
\hline
\end{tabular}

ching curves show plateaus beginning around days 125,210 and 260, respectively. Successive interruptions lasted for 61 (58-65), 48 or 46, and 41 days, respectively, as opposed to 35 days long cold exposures.

$\therefore$ The slowest egg mass kept hatching slowly but steadily after the first interruption, also during cold exposure, until it reached over $60 \%$ hatch; it then showed a belated reaction to cold exposure.

\subsection{Importance of developmental stage}

Interruptions of embryogenesis after 2, 3, 4 or 5 weeks, respectively, affecting eggs in different stages of development had no recognizable effect on hatching success. The various patterns of hatching were also unrelated to stage of development. Only the relative length of successive interruptions of development (Figs. 5, 7) indicated that impact on development lessened with increasing age of embryos.

\subsection{Field conditions versus constant laboratory conditions}

Daily mean temperatures in the Breitenbach during the experiment ranged between 9.3 and $11.8^{\circ}$, with daily amplitudes of $c a 5-7^{\circ}$ (Fig. 8). Overall mean temperature was $10.9^{\circ}$. The six egg masses hatched synchronously and reached mean hatch after 84.6 (82-89) days in the Breitenbach, corresponding to a mean of 589 degreedays above the $4^{\circ} \mathrm{C}$ threshold; this agrees with laboratory data (Zwick 1996).

\subsection{Effect of suboptimal temperatures above threshold}

The eleven egg masses began hatching synchronously, after 99-101 days. Only two egg masses exhibited unimodal but very extended hatching (Fig. 9). Mean incubation periods were 159 and 162 days, respectively, which is long for incubation at $10^{\circ}$ (Zwick 1996). 


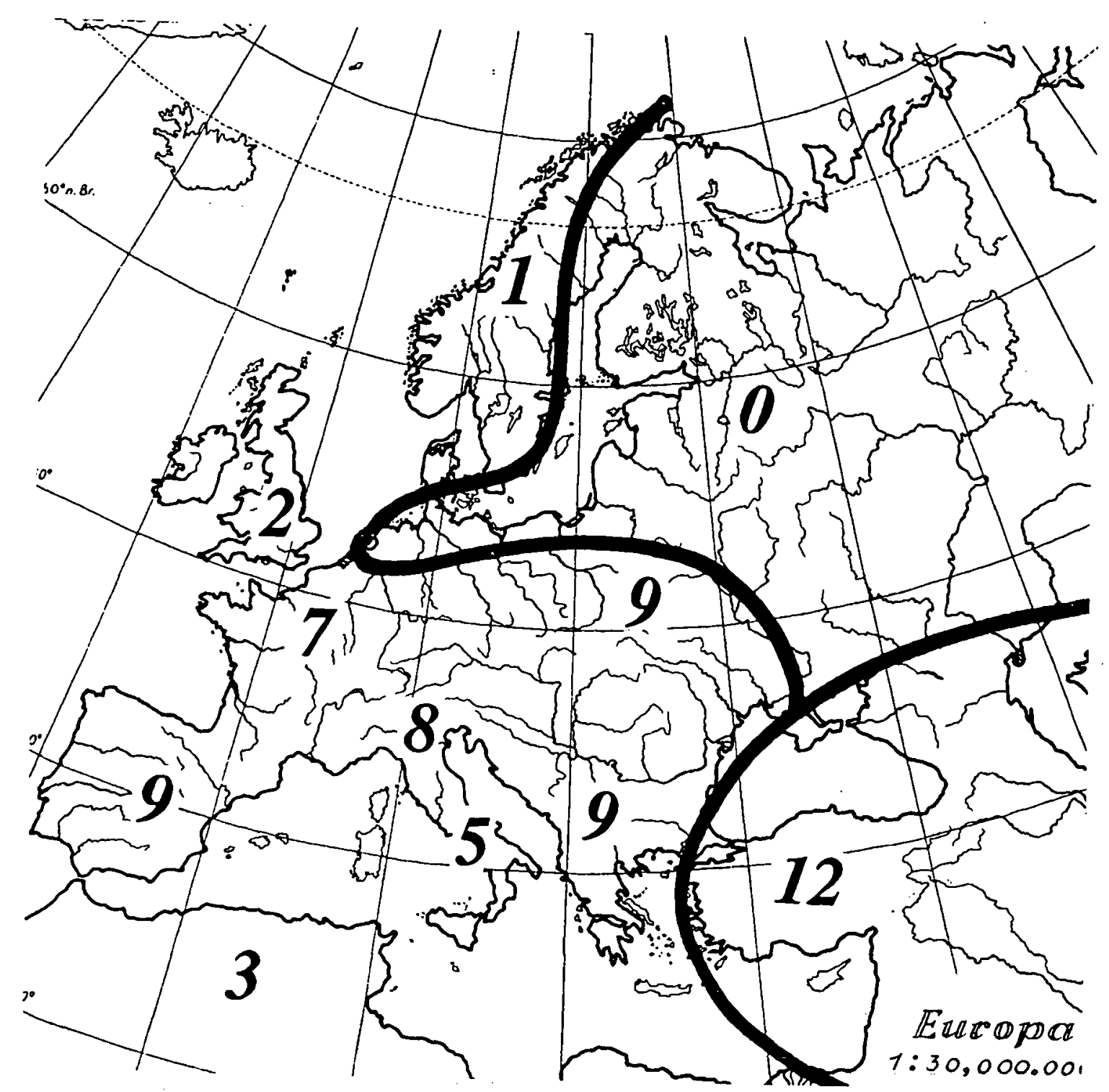

Fig. 1. Species diversity of European Perlidae; data from Fochetti (1995), Illies (1966) and Zwick (1973).

Fig. 1. Diversité spécifique des Perlidae d'Europe ; données de Fochetti (1995), Illies (1966) et Zwick (1973)

Hatching from the other egg masses stopped after some time, despite the fact that conditions did not change. Hatching was later resumed; subsequent behaviour differed much between egg masses, but all eventually attained high hatching success (Table 3 ). No eggs remained dormant at $10^{\circ}$ for long periods of time.

Six egg masses exhibited remarkably synchronous bi- or trimodal patterns of hatching (Fig. 10). Batch H95-5 had also bimodal hatch but hatching peaked at different times. Two batches (H95-6 and H95-10, fig. 11; Table 3) exhibited irregular extended hatching; there was partial agreement with timing of hatching pulses of the other egg masses.

\subsection{Effect of cold on larval hatching}

During alternate exposure to cold and warm water, several examples of continued hatching during cold exposure were observed (HA, $\mathrm{HI}$ in fig. $4, \mathrm{HC}$ in fig. 7). An experiment specifically conducted to answer the present question, hatching from fully developed eggs previously kept at $19^{\circ} \mathrm{C}$ continued in all batches, despite cooling to $4^{\circ}$. Patterns differed; in some egg masses, hatching continued steadily, in others it speeded up after a short while at $4^{\circ}$, resulting in an almost normal sigmoid cumulative hatching curve. After 78 days at $4^{\circ}$, between $10-85 \%$ of the eggs that were initially present when eggs were cooled had hatched. From batches then still containing many eggs numerous additional larvae hatched when temperature was raised to 20. After 3 weeks hatching levelled off, and temperature was raised to $30^{\circ}$, but there was no effect. In the end, most batches had overall hatching success of $89 \%(78-100 \%)$. Two batches were distinctly less successful. In one of them ( $42 \%$ success) the remai- 


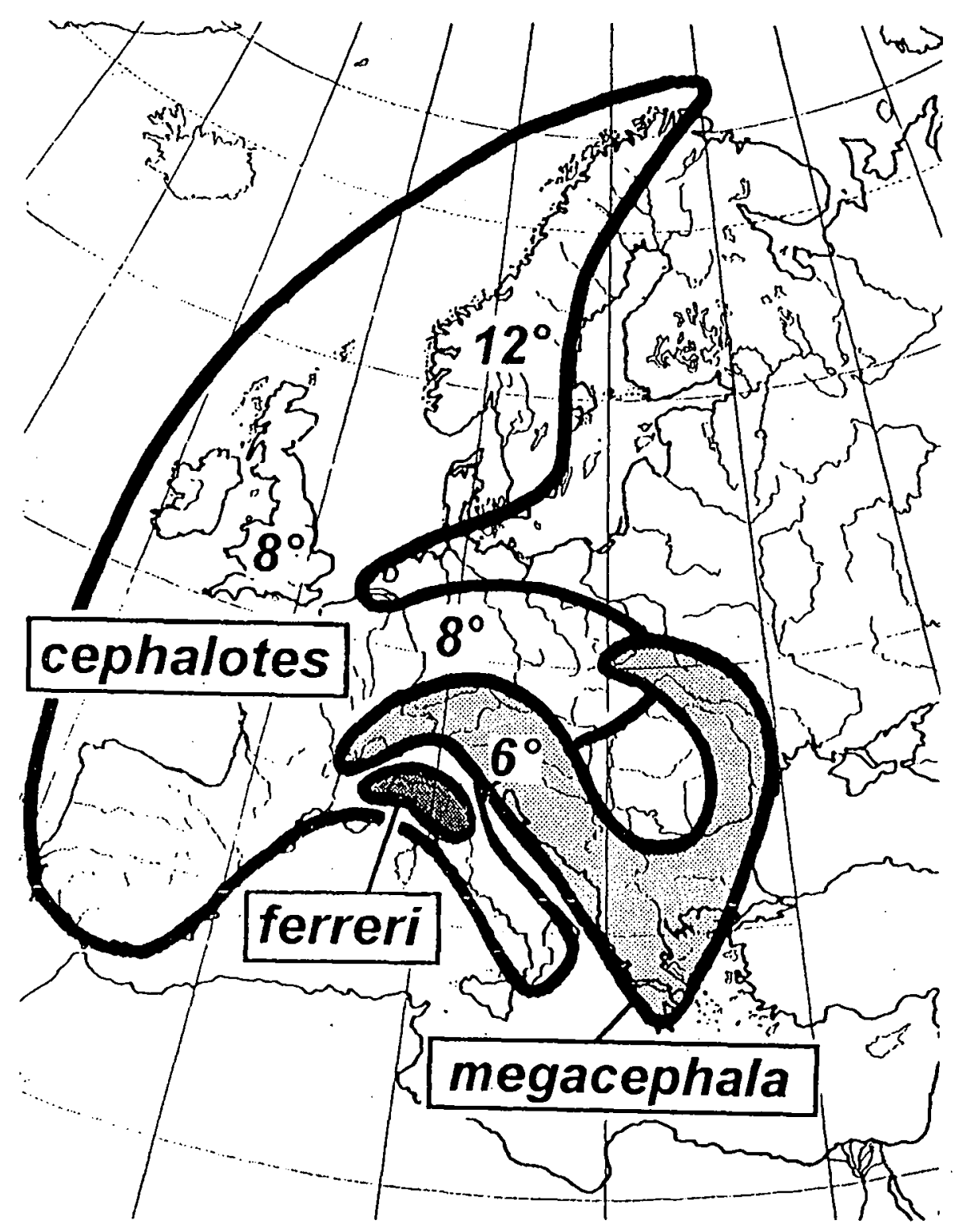

Fig. 2. Distribution of Dinocras spp. and cue temperatures required to release egg development.

Fig. 2. Distribution de Dinocras spp. et les températures qui déterminent le déclenchement du développement des œufs.

ning eggs were not visibly developed and dead, perhaps unfertilized; in the other ( $57 \%$ success) most unhatched eggs were fully developed, at the eyespot stage.

\section{Discussion}

The results show that Dinocras cephalotes is able to interrupt and resume egg development repeatedly, at a variety of developmental stages, without marked reduction of overall hatching success (Table 1); exceptions are not outside the range observed during uninterrupted development (Zwick 1996). The species has the potential of using summer warmth during successive years by extending its embryogenesis over more than a single year.

Morphological details and actual stops of embryogenesis during cold exposure were not monitored, because the dark egg shells are little transparent. However, well defined plateaus in cumulative hatching curves «echoing» earlier cold exposure showed that development was indeed completely interrupted at $4^{\circ}$. Both halt and recommencement of hatching were abrupt.

Halt of development was a direct and apparently immediate reaction to cold; the rest would therefore be a quiescence in the terminologies of Danks (1987) and Müller (1992). In such case, development should be resumed immediately when water warms again. However, development was resumed with delay; this suggests that once development is interrupted eggs quickly enter a very deep rest, probably a thermal parapause.

Mean incubation periods were longer than during uninterrupted development (Table 2), with a single exception (HG in Fig. 7). However, measuring these delays was difficult. For example, egg masses in Fig. 6 


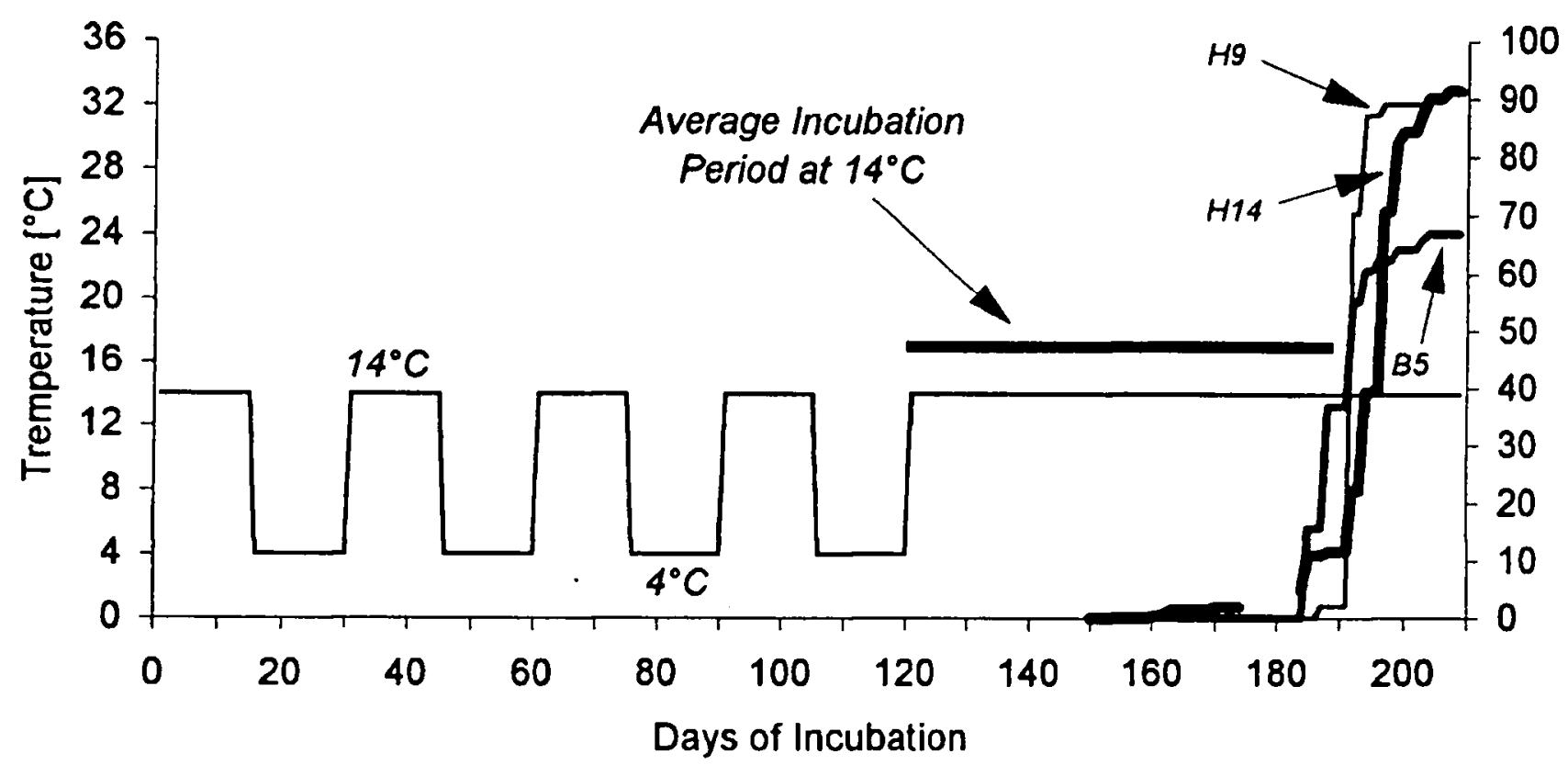

Fig. 3. Dinocras cephalotes, examples of cumulative hatching curves under an experimental temperature regime alternating between $4^{\circ}$ and $14^{\circ} \mathrm{C}$, starting at $14^{\circ}$; changes of temperature occurred every 2 weeks. Two additional egg masses not shown were intermediate between curves $\mathrm{H}_{9}$ and $\mathrm{H}_{14}$.

Fig. 3. Dinocras cephalotes, exemples de courbes cumulées des éclosions sous un régime de températures de $4^{\circ}$ et $14^{\circ} \mathrm{C}$ en alternance et débutant à $14^{\circ} \mathrm{C}$; les changements de température avaient lieu chaque 2 semaines. Deux masses d'œufs supplémentaires, non représentées ici, étaient intermédiaires entre les courbes $\mathrm{H}_{9}$ et $\mathrm{H}_{14}$

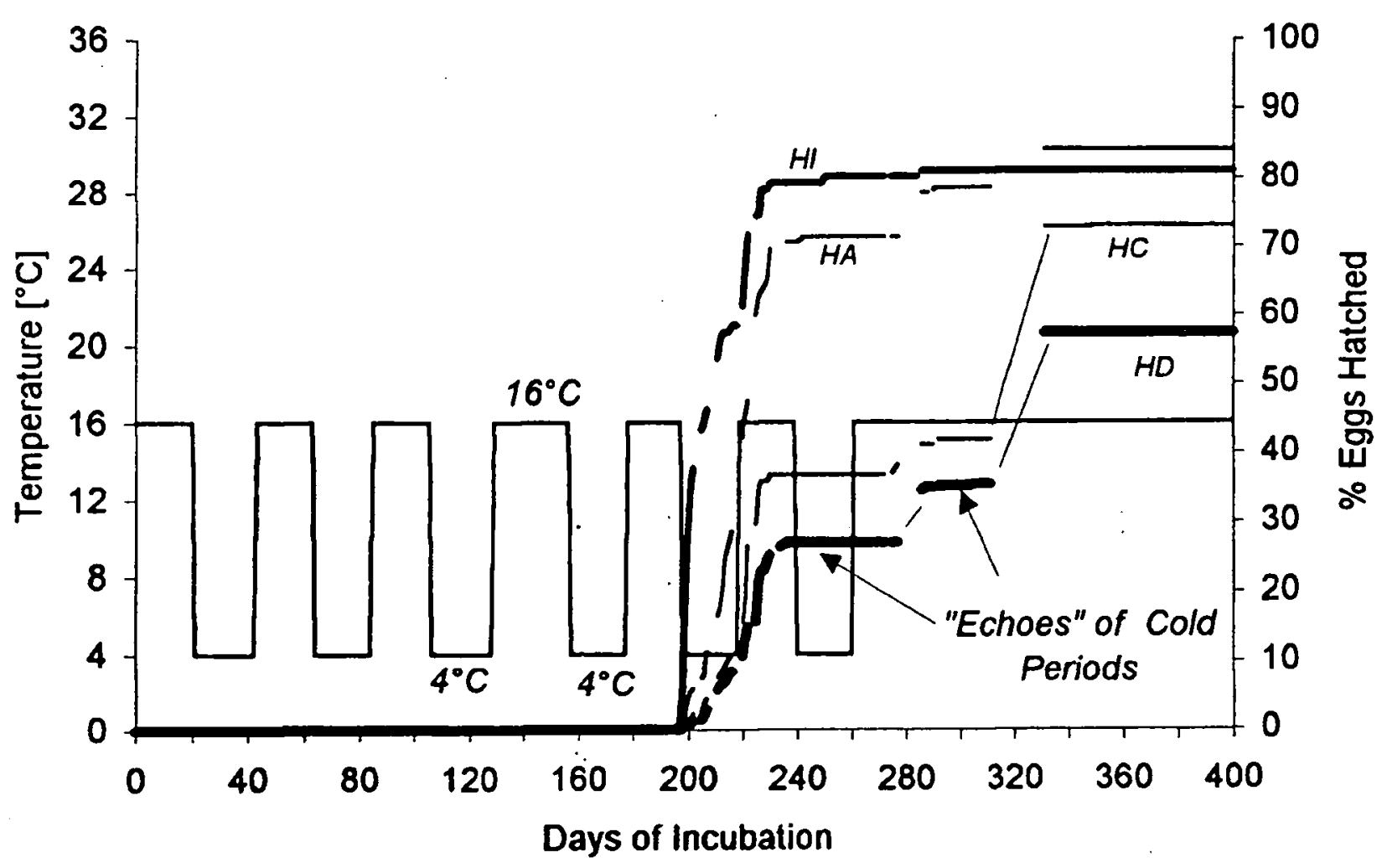

Fig. 4. Dinocras cephalotes, cumulative hatching curves under an experimental temperature regime alternating between $4^{\circ}$ and $16^{\circ} \mathrm{C}$, starting at $16^{\circ}$; changes of temperature occurred every 3 weeks.

Fig. 4. Dinocras cephalotes, courbes cumulées des éclosions sous un régime de températures de $4^{\circ}$ et $16^{\circ} \mathrm{C}$ en alternance et débutant à $16^{\circ}$; les changements de températures avaient lieu chaque 3 semaines. 


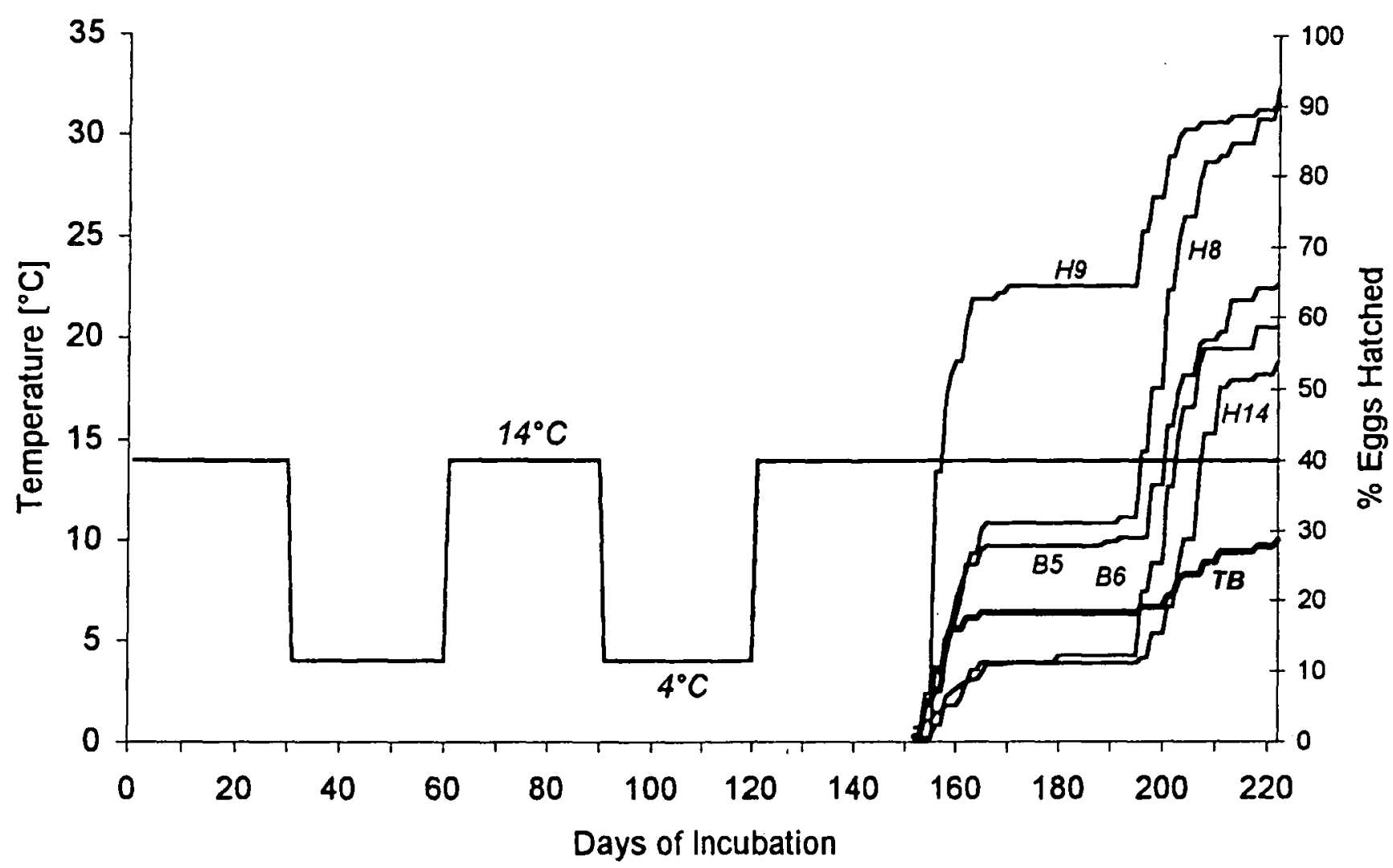

Fig. 5. Dinocras cephalotes, cumulative hatching curves under an experimental temperature regime alternating between $4^{\circ}$ and $14^{\circ} \mathrm{C}$, starting at $14^{\circ}$; changes of temperature occurred every 4 weeks.

Fig. 5. Dinocras cephalotes, courbes cumulées des éclosions sous un régime de températures de $4^{\circ}$ et $14^{\circ} \mathrm{C}$ en alternance et débutant à $14^{\circ}$; les changements de température avaient lieu chaque 4 semaines.

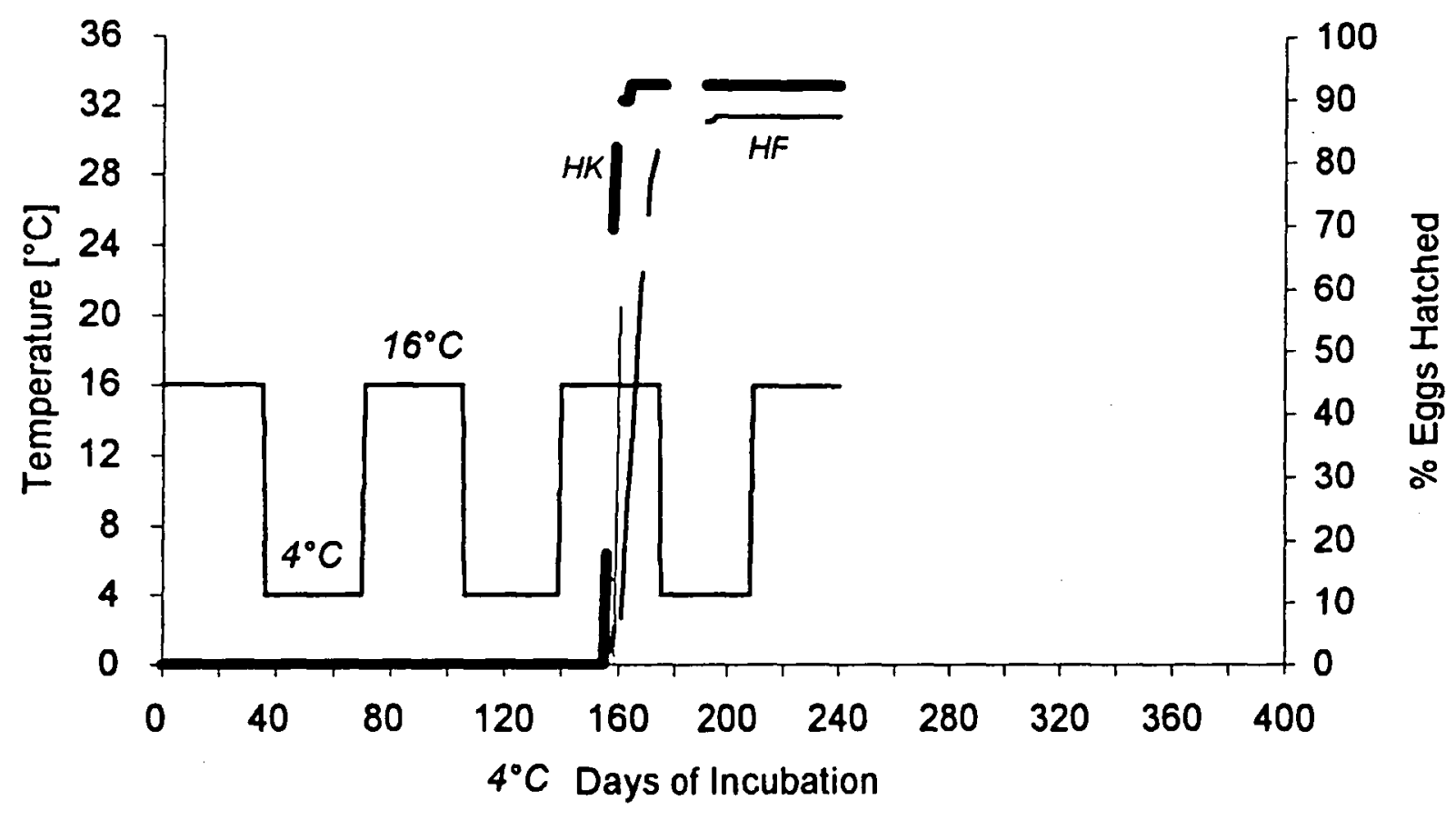

Fig. 6. Dinocras cephalotes, cumulative hatching curves under an experimental temperature regime alternating between $4^{\circ}$ and $16^{\circ} \mathrm{C}$, starting at $16^{\circ}$; changes of temperature occurred every 5 weeks. Only the slowest and the fastest of four egg masses are shown.

Fig. 6. Dinocras cephalotes, courbes cumulées des éclosions sous un régime de températures de $4^{\circ}$ et $16^{\circ} \mathrm{C}$ en alternance et débutant à $16^{\circ}$; les changements de température avaient lieu chaque 5 semaines. Seule la plus lente et la plus rapide des 4 masses d'œufs sont figurées. 


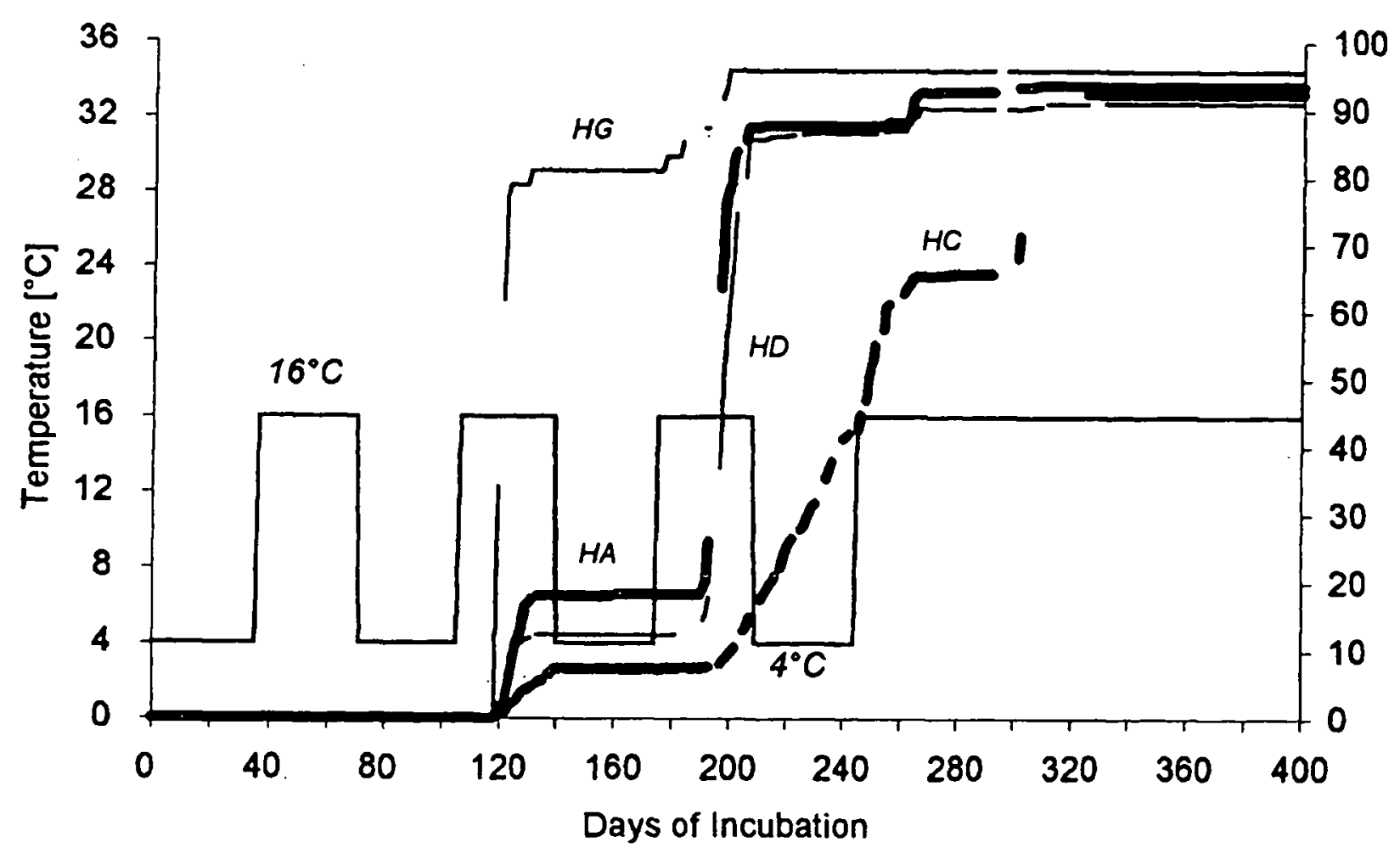

Fig. 7. Dinocras cephalotes, cumulative hatching curves under an experimental temperature regime alternating between $4^{\circ}$ and $16^{\circ} \mathrm{C}$, starting at $4^{\circ}$; changes of temperature occurred every 5 weeks.

Fig. 7. Dinocras cephalotes, courbes cumulées des éclosions sous un régime de températures de $4^{\circ}$ et $16^{\circ} \mathrm{C}$ en alternance et débutant à $4^{\circ}$; les changements de température avaient lieu chaque 5 semaines.

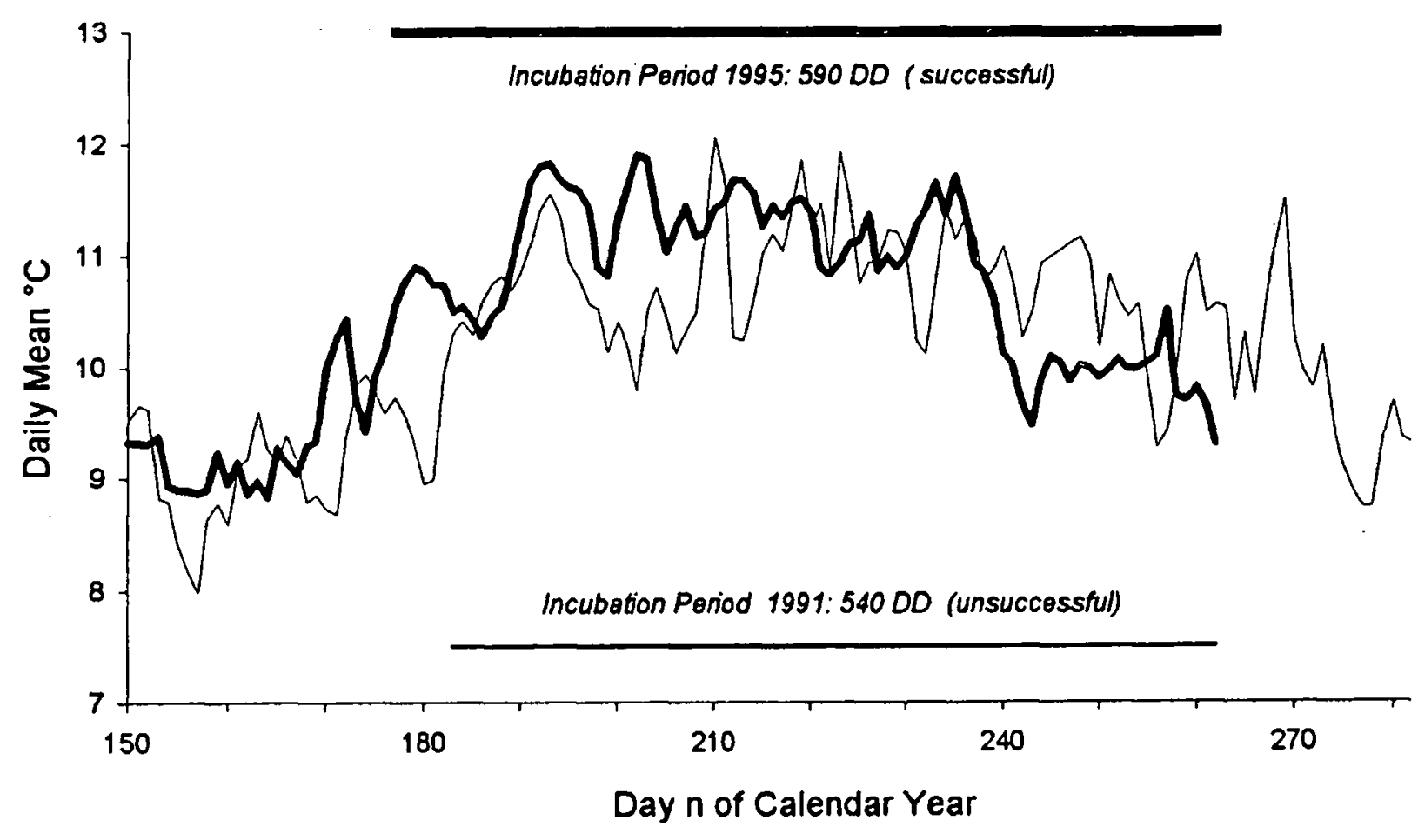

Fig. 8. Dinocras cephalotes, incubation periods (bars) and thermal sums acquired in the Breitenbach in 1991 (unsuccessful) and 1995 (successful) and daily mean water temperatures (based on automatic readings every $15 \mathrm{~min}$ ) in the two years.

Fig. 8. Dinocras cephalotes, périodes d'incubation (traits) et sommes de températures relevées dans le Breitenbach en 1991 (sans succès) et 1995 (avec succès) et températures moyennes journalières de l'eau (enregistrement automatique chaque $15 \mathrm{~min}$.) pour les deux années. 

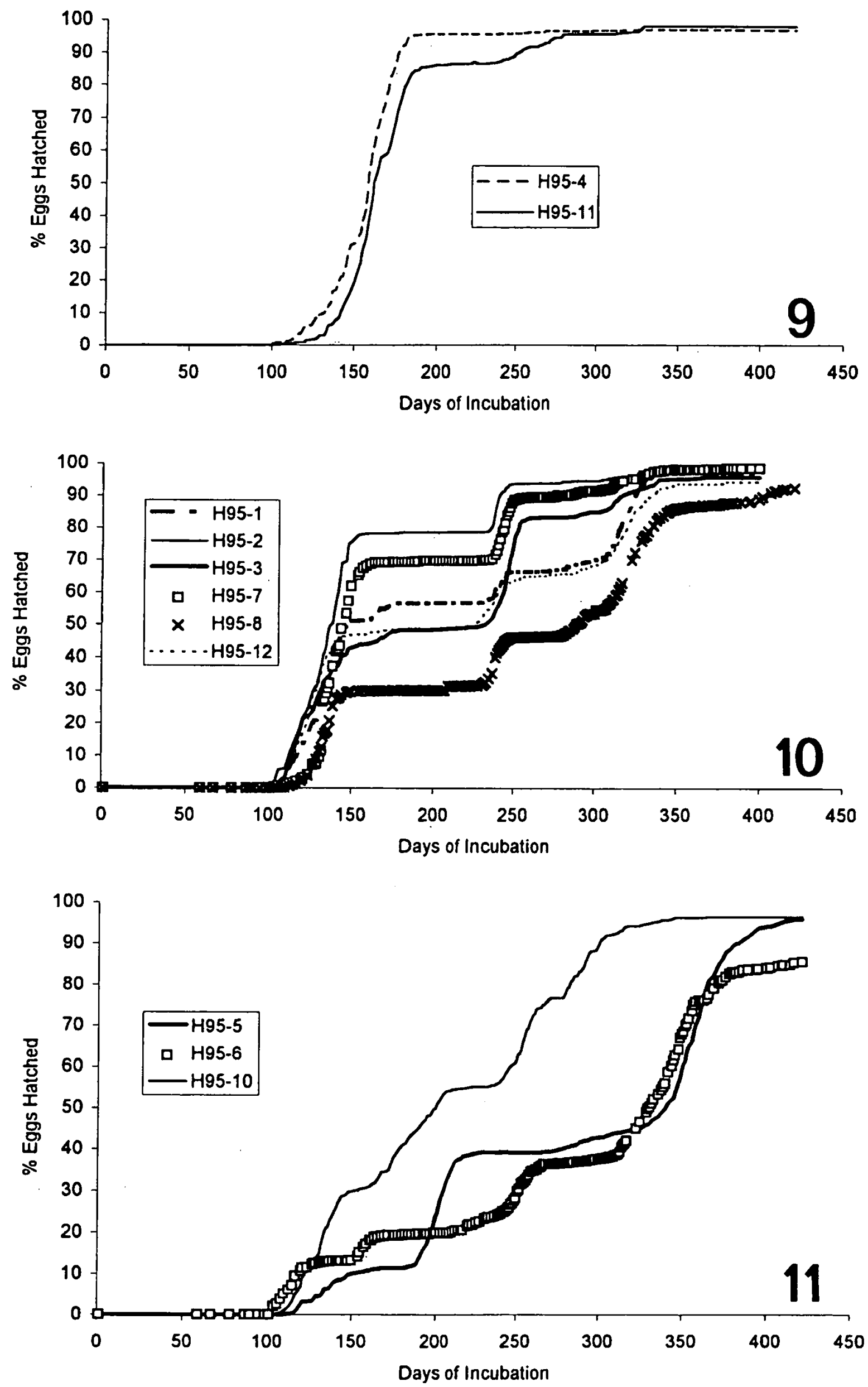

Figs. 9-11. Dinocras cephalotes, cumulative hatching curves of eggs collected at the stream on the same day and incubated together at suboptimal $10^{\circ} \mathrm{C}$ for over 350 days. 9: two batches with unimodal hatch. 10: six batches with similar plurimodal pattern of hatch. 11: irregular plurimodal hatching curves.

Figs. 9-11. Dinocras cephalotes, courbes cumulées des éclosions des œufs récoltés le même jour dans la rivière et incubés ensemble à la température suboptimale de $10^{\circ} \mathrm{C}$ pendant plus de 350 jours. $9: 2$ lots avec éclosion unimodale. 10:6 lots avec mode plurimodal d'éclosion comparable. 11 : courbes d'éclosions plurimodales irrégulières. 
Table 2. Dinocras cephalotes, Bavarian (B), Hessian (H) and Thuringian ( $\mathrm{T}$ ) batches under various treatments (see Table 1): Day of mean hatch [Day $50 \%$ ], number of days spent in warm water, number of halts of development during cold exposure, number of days mean hatch is delayed when compared with continuous incubation under the same respective warm temperature, and number of days delayed per halt.

Tableau 2. Dinocras cephalotes, lots de Bavière $(B)$. Hesse $(H)$ et Thuringe $(T)$ sous traitements variés (voir Tableau 1). Nombre de jours nécessaires à l'éclosion de $50 \%$ de larves [day $50 \%$ ], nombre de jours passés en eau chaude, nombre d'arrêts de développement pendant l'exposition au froid, nombre de jours de retard de l'éclosion moyenne par comparaison avec une incubation continue à la même température respective et nombre de jours de retard par arrêt.

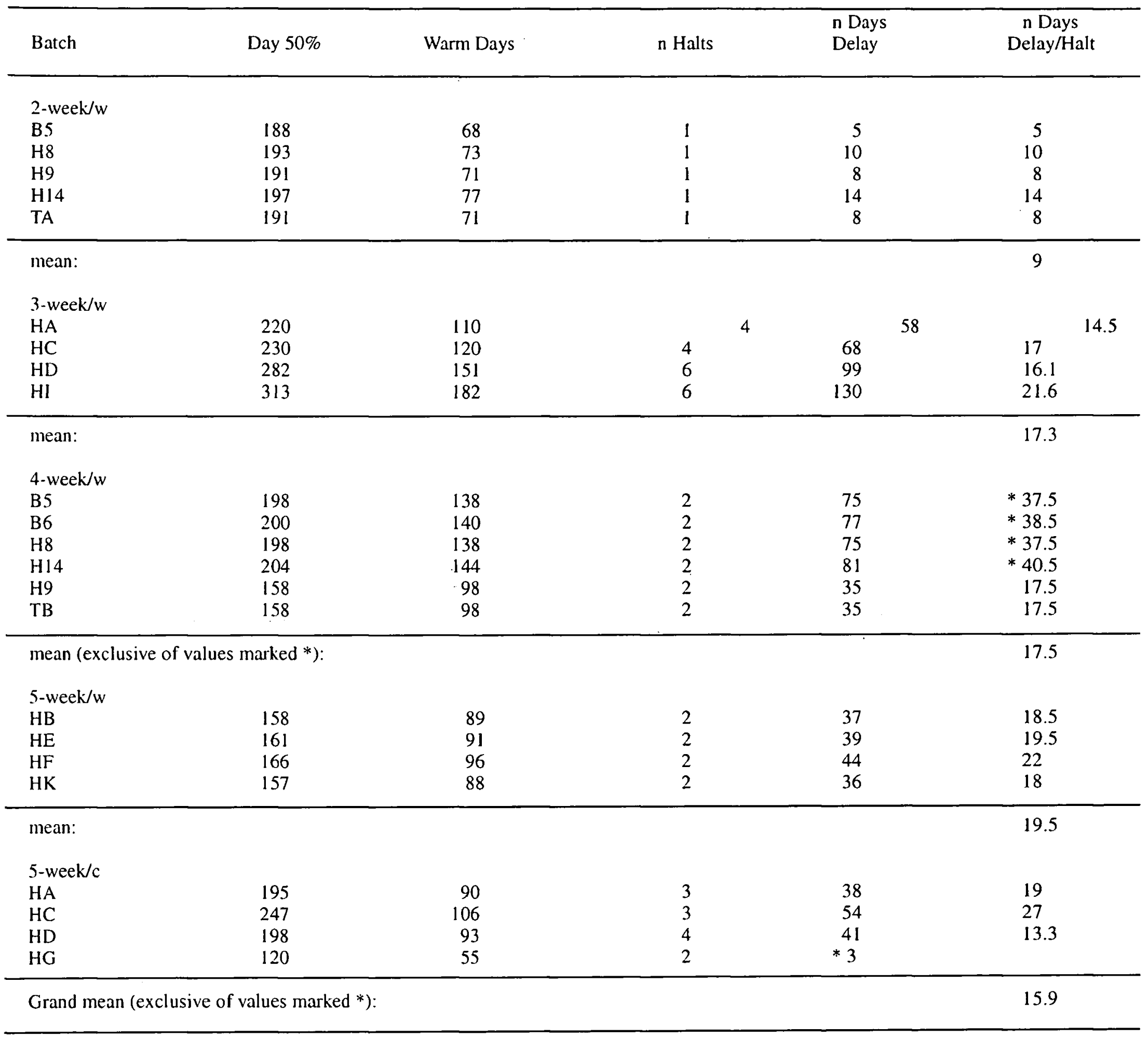

exhibited virtually identical patterns of hatching, but the arbitary definition of mean incubation period as the reference point led to very different estimates of delay; it seems to have been grossly overestimated in 4 of the 6 egg masses. If these aberrant values are excluded, a mean delay of slightly over two weeks per cooling event results (Table 2).

This explains why there was no development during the two-week treatment. However, development started once eggs were continuously kept at $14^{\circ}$. and mean 
Table 3. Dinocras ceplalotes, eleven egg masses collected on a $100 \mathrm{~m}$ stretch of the Birxbach, Germany, 26 June 1995, incubated under constant $10^{\circ} \mathrm{C}$ : Hatching patterns, days on which $50 \%$ of larvae hatching during a given pulse of hatching had actually hatched, total number of larvae hatched and overall hatching success [\% of all eggs] after 420 days at $10^{\circ} \mathrm{C}$.

Tableau 3. Dinocras cephalotes, onze masses d'œufs récoltées, sur une zone de $100 \mathrm{~m}$ du Birxbach (Allemagne), 26 juin 1995 , incubés à la température constante de $10^{\circ} \mathrm{C}$ : modes d'éclosions, nombre de jours nécessaires à l'éclosion de $50 \%$ de larves, pendant un pic donné d'éclosions, nombre total de larves écloses et taux de réussite global des éclosions (\% de tous les œufs) après 420 jours à $10^{\circ} \mathrm{C}$.

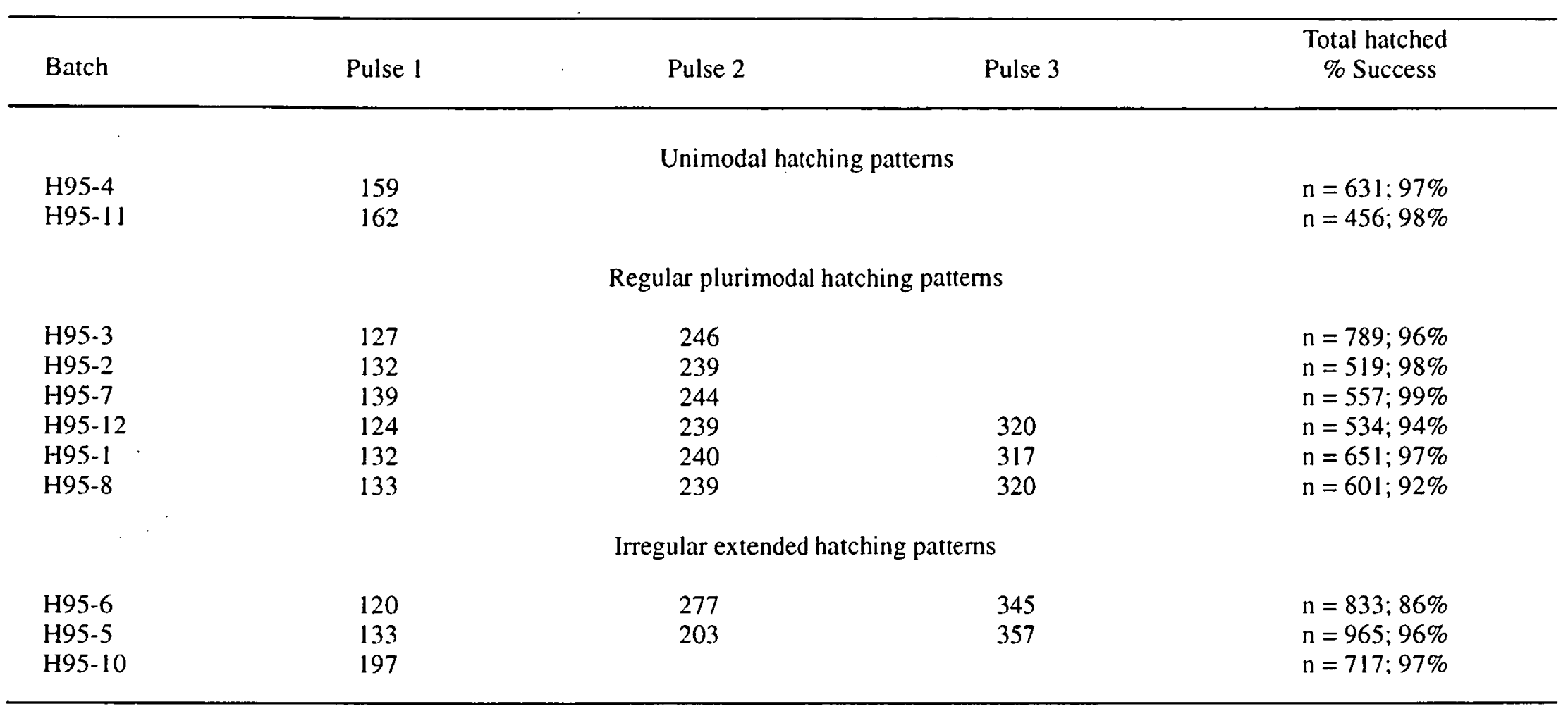

hatch was little later than expected at constantly $14^{\circ}$ (63 days; Zwick 1996).

The different starting temperatures in combination with the delays after cooling also explain the difference between the three-week treatments starting at $4^{\circ}$ and at $16^{\circ}$, respectively. During continuous incubation at $16^{\circ}$, mean incubation period is 52 days (Zwick 1996). After the cold start, warmth was effective only during one week of each three-week warm exposure; about 42 effective warm days had been experienced and hatching just started before samples were lost after 251 days.

In contrast, eggs starting development in warm water fully exploited the initial three-week warm exposure, plus another week during each subsequent warm period; by mistake, one too long warm period was also administered (see Fig. 4). Altogether, there had been about 56 effective days at $16^{\circ}$ when eggs were 230 days old and massive hatch occurred.

Different lengths of successive interruptions of hatching upon cold exposure suggest that embryos become less sensitive against cold as they grow older. The fact that fully developed embryos hatched even in very cold water is in line with this notion. In the field, fully developed embryos of $D$. cephalotes probably continue hatching during cold seasons. In this respect, $D$. cephalotes differs from the North American perlid, Paragnetina media (Walker) and from Pteronarcys proteus Newman whose fully developed embryos spend winter in the eggs and hatch only as soon as water warms in spring (Harper 1973, Miller 1939). Both behaviours were also observed among Perlodidae (Schwarz 1970). This problem was not considered in Agnetina capitata (Pictet) whose egg development seems to have otherwise much in common with the present species (Moreira \& Peckarsky 1994).

Batches incubated at $10^{\circ}$, a suboptimal temperature above the lower threshold, eventually all developed instead of entering long-lasting parapause. Batches for this experiment were collected from a $100 \mathrm{~m}$ stretch of the Birxbach, on the same morning; yet, hatching patterns were very different. This provided excellent evidence for the heterogeneity of the population and also for marked differences between siblings in a single batch. The first and second hatching pulses (Figs. 911; Table 3 ) of most egg masses were synchronous, despite the lack of stimuli under the constant regime; apparently, the behaviour of the eggs is indeed genetically determined (Zwick 1996). 
Inferences from laboratory experiments with German $D$. cephalotes on the situation of the species in the field are legitimate. Previous studies have shown that temperature response of embryogenesis agrees between different populations of Dinocras spp., except for a latitudinal gradient in cue temperatures at which spontaneous development occurs (Elliott 1989, Lillehammer 1986, Zwick 1996). Also, earlier (Elliott 1989, Zwick 1996) and present comparisons of incubation of $D$. cephalotes under natural field and constant laboratory conditions, respectively, revealed no differences in mean incubation periods and thermal sums until mean hatch. The same is true of most Plecoptera (Brittain 1977, Elliott 1987, 1988, 1991a, b, Marten 1990b), but not of all (Lillehammer et al. 1991).

Incubation in the epirhithral Breitenbach (at $50^{\circ} 40^{\prime} \mathrm{N}, 220 \mathrm{~m}$ a.s.l.) showed that already this would be a marginal habitat for $D$. cephalotes. In 1991 and 1995, mean water temperatures were almost the same, but temperature patterns differed: June and July were cooler in 1991 than in 1995, when August and September were cooler than in 1991. That earlier developmental stages are more sensitive to cold than later stages may have been important for the outcome. In 1991, eggs accumulated only 540 degreedays above $4^{\circ}$ before frost, only 3 out of many egg masses hatched before winter (Zwick 1996). In 1995, all egg masses attained mean hatch when they had accumulated 589 degreedays (Fig. 8).

Temperature data are not available on the metarhithral stream section of the Birxbach which supports a large population and where specimens were collected. The metarhithron is the preferred central European habitat of the species (Graf et al. 1995). According to temperature regimes characteristic of different stream sections (Moog \& Wimmer 1994), the more montane Birxbach may in summer have warmer water than the Breitenbach. It is unknown if Dinocras eggs laid in the Birxbach hatch the same or the following year.

In Lapland, D. cephalotes eggs are laid in the end of July and at best half the required thermal sum is available to them in the same year (temperature data from Ulfstrand 1968); hatching in the same year seems to be out of the question. However, the present results and data on longevity of dormant $D$. cephalotes eggs (Lillehammer 1987, Zwick 1996) suggest that the species can make opportunistic use of summer warmth during more than one year, probably without much damage to hatching success. Spread of egg development over two, perhaps even more years is here suggested as the mechanism by which this warm stenotherm stonefly satisfies its high thermal demand at high northern latitudes.

The paradoxical latitudinal gradient of minimum cue temperatures (Fig. 2) requires explanation. Access to Scandinavia across postglacial land-bridges to western and central Europe was possible only during a restricted time (Segerstrale 1957). Access must have been difficult for Perlidae requiring hard bottom substrata; these are largely absent from streams in the sandy lowlands south of the Baltic and North Seas which today are void of the genera Dinocras and Perla. The reduced genetic diversity might therefore result from chance dispersal and founder effects.

However, the reduced diversity in the north may also result from selection. As shown above, larval eclosion from eggs is not prevented by cold temperatures; the high cue temperatures may be important in seasonal adjustment, preventing larval hatching under temperature conditions unfavourable for the early larval instars. Low temperatures are apparently generally unfavourable, perlid larval growth stops during winter. This is so not only in North Europe, where larvae grow at best during 3 months every year (Huru 1987) but also under more benign conditions in central Europe (at $600 \mathrm{~m}$ a.s.l. in the lower Swiss Alps; D. cephalotes: Frutiger 1987; Perla grandis Rambur: Imhof 1994). The case of $D$. cephalotes is probably not unique, Perla grandis seems to be similar (my own unpublished data) and the same is suggested by data on Perlodidae and other Perlidae (Marten 1991, Moreira \& Peckarsky 1994). A final conclusion requires additional detailed information on sensitivity of different larval stages and on actual life history of $D$. cephalotes in arctic Europe.

\section{Acknowledgements}

Mrss G. Stüber and E. Döring did much of the laboratory work and are sincerely thanked. H.-H. Schmidt is thanked for the temperature data from automatic recordings in the Breitenbach.

\section{References}

Brittain J.E. 1977. - The effect of temperature on the egg incubation period of Taeniopteryx nebulosa (Plecoptera). Oikos, 29: 302-305.

Danks H. V. (1987). - Insect Dormancy: An Ecological Perspective. Biol. Surv. Can., Monograph 1: I-X + 440 p.

Elliott J. M. 1987. - Egg hatching and resource partitioning in stoneflies: The six British Leuctra spp. (Plecoptera: Leuctridae). J. Anim. Ecol., 56: 415-426.

Elliott J. M. 1988. - Egg hatching and resource partitioning in stoneflies (Plecoptera): Ten British species in the family Nemouridae. J. Anim. Ecol., 57: 201-215.

Elliott J. M. 1989. - The effect of temperature on egg hatching for three populations of Dinocras cephalotes (Plecoptera: Perlidae). Entomol. Gazette, 40: 153-158. 
Elliott J. M. 1991a. - The effect of temperature on egg hatching for three populations of Isoperla grammatica and one population of Isogenus mubecula (Plecoptera: Perlodidae). Entomol. Gazette, 42: $61-65$.

Elliott J. M. 1991b. - The effect of temperature on egg hatching for three populations of Perla bipunctata (Plecoptera: Perlidae). Entomol. Gazetle, 42: 99-103.

Elliott J. M. 1995. - Egg hatching and ecological partitioning in carnivorous stoneflies (Plecoptera). C. R. Acad. Sci., Paris, Sciences de la vie. Biologie et pathologie animale, 318: 237-243.

Fochetti R. 1995. - Plecoptera. - Fasc. 37, 6 pp., in: Minelli, A., Ruffo, S. and La Posta, S. (eds): Checklist delle specie della fauna Italiana. Ministerio dell' Ambiente e Comitato Scientifico per la Fauna d'Italia; Calderini, Bologna.

Frutiger A. 1987. - Investigations on the life-history of the stonefly Dinocras cephalotes Curt. (Plecoptera: Perlidae). Aquatic Insects, 9: $51-63$.

Graf W., Grasser U. \& Weinzierl, A. 1995. - Plecoptera (Steinfliegen). Teil 3A, 4pp.; Teil 3B, 4pp.; Teil 3C, 4pp.; Teil 3D, 4pp.; Teil 3E, pp.5-6. - in Moog, O. (ed.) Fauna aquatica Austriaca. Wasserwirtschaftskataster, Bundesministérium f. Land- u. Forstwirtschaft, Wien.

Harper P.P. 1973. - Emergence, reproduction and growth of setipalpian Plecoptera in Southern Ontario. Oikos, 24: 94- 107.

Huru H. 1987. - Occurrence and life cycle of Dinocras cephalotes (Curtis, 1827) (Plec. Perlidae) in North Norway. Faun. norv. Ser: B., 34: 14-18.

Illies J. 1966. - Katalog der rezenten Plecoptera. Das Tierreich 82: I-XXX, 1-631.

Imhof, A. 1994. - Habitatsansprüche und Verhalten von Perla grandis Rambur (Plecoptera: Perlidae) und anderen räuberischen Steinfliegenlarven. Doctoral thesis, Dissertation No. 10695, Eidgenössische Technische Hochschule Zürich, $152 \mathrm{p}$.

Lillehammer A. 1986. - Egg development of the stoneflies Siphonoperla burmeisteri (Chloroperlidae) and Dinocras cephalotes (Perlidae). Freshiriat. Biol. , 16: 35-39.

Lillehammer A. 1987. - Diapause and quiescence in eggs of Systellognathan stonefly species (Plecoptera) occurring in alpine areas of Norway. Annls Limnol. 23: 179-184.

Lillehammer A. 1988. - Stoneflies (Plecoptera) of Fennoscandia and Denmark. Fauna Entomol. Scand. 21, 165 p.

Lillehammer A., Saltveit, S.J. \& Brusven, M. 1991. - The influence of variable temperatures on the incubation period of stonefly eggs (Plecoptera): 377-385 in Alba-Tercedor, J. and Sanchez-Ortega, A. (eds): Overview and Strategies of Ephemeroptera and Plecoptera. Sandhill Crane Press, Inc., Gainesville, Fla., XIV + $588 \mathrm{p}$.
Marten M. 1990a. - A new thermostat-controlled waterbath which provides eight constant temperatures for the price of one. Hydrobiologia. 194: 199-201.

Marten M. 1990b. - Interspecific variation in temperature dependence of egg development of five congeneric stonefly species (Protonemura Kempny, 1898, Nemouridae, Plecoptera). Hydrobiologia, 199: 157-171.

Marten M. 1991. - The effect of temperature on the egg incubation period of Perlodes microcephalus, Perlodes dispar (Plecoptera: Perlodidae) and Perla burmeisteriana (Plecoptera: Perlidae): 387. 401 in Alba-Tercedor J. and Sanchez Ortega A. (eds): Overview and Strategies of Ephemeroptera and Plecoptera. Sandhill Crane Press, Inc., Gainesville, Fla., XIV + 588 p.

Miller A. 1939. - The egg and early development of the stonefly Pteronarcys proteus Newman (Plecoptera). J. Morph.. 64: 555609.

Moog O. \& Wimmer R. 1994. - Comments on the water temperature based assessment of biocoenotic regions according to Illies and Botosaneanu. Verh. Internat. Verein. Limnol., 25: 1667-1673.

Moreira G.R.P. \& Peckarsky B.L. 1994. - Multiple developmental pathways of Agnetina capitata (Plecoptera: Perlidae) in a temperate forest stream. J. N. Am. Benthol. Soc., 13: 19-29.

Müller H. J. 1992.-Dormanz bei Arthropoden. Jena, Gustav Fischer Verlag: $290 \mathrm{p}$.

Sanchez-Ortega A. \& Alba-Tercedor J. 1991. - The life cycle of Perla marginata and Dinocras cephalotes in Serria [sic!] Nevada (Granada, Spain) (Plecoptera: Perlidae): 493-501 in Alba-Tercedor, J. and Sanchez-Ortega, A. (eds): Overview and Strategies of Ephemeroptera and Plecoptera. - Sandhill Crane Press, Inc., Gainesville, Fla., XIV + 588 p.

Schwarz P. 1970. - Autökologische Untersuchungen zum Lebenszyklus von Setipalpia-Arten (Plecoptera). Arch. Hydrobiol., 67: 103-140.

Segersträle S. G. 1957. - Baltic Sea. - Treatise on Marine Ecology and Palaeontology, Vol.1; Geol. Soc. Amer., Mem. 67, quoted from Arndt, E. A. 1964. - Tiere der Ostsee. Neue Brehm Bïcherei 328; A. Ziemsen Verlag, Wittenberg Lutherstadt.

Ulfstrand S. 1968. - Life cycles of benthic insects in Lapland streams (Ephemeroptera, Plecoptera, Trichoptera, Diptera Simuliidae). Oikos, 19: 167-190.

Zwick P. 1973. - Insecta Plecoptera. Phylogenetisches System und Katalog. Das Tierreich 94: I-XXXII, 1-465.

Zwick P. 1996. - Variable egg development of Dinocras spp. (Ins.: Plecoptera, Perlidae) and the stonefly seed-bank-theory. Freshwat. Biol., 35: 81-100. 